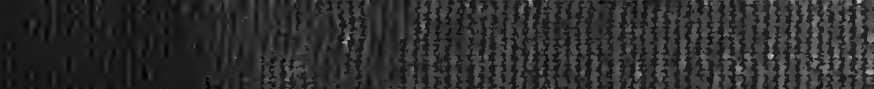

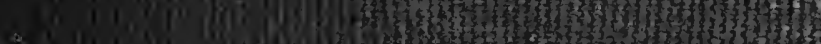

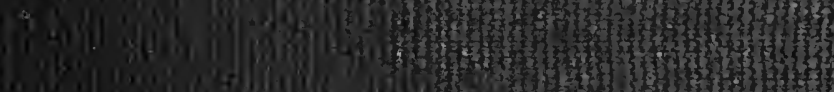
W.1.

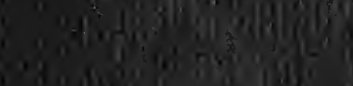
(n)

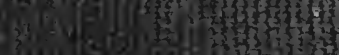

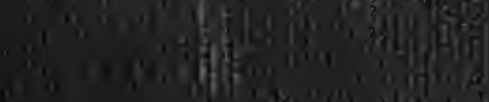



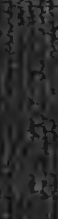

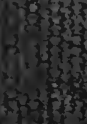




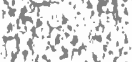

Ifing

fols

ind

$4 y^{2}$

3 o

side

os

tow the

a 


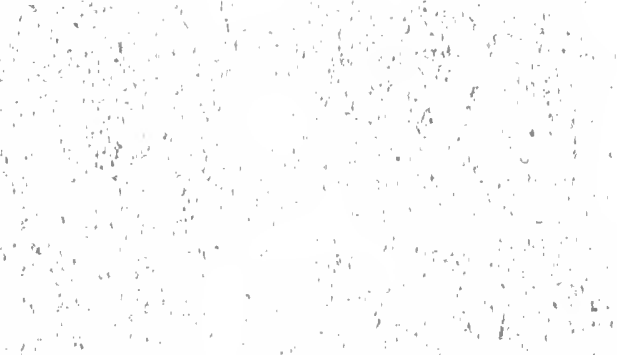

8
$\because$



48

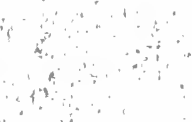


THE ESSENTIALS OF A WRITTEN CONSTITUTION 
Digitized by the Internet Archive in 2008 with funding from Microsoft Corporation 


\title{
THE ESSENTIALS OF A WRITTEN CONSTITUTION
}

\author{
Harri Pratt JUdSON
}

Since the year of the Declaration of Independence of the United States there have been created a long series of written constitutions. Each of the original thirteen states of the American Union set forth its fundamental law in statutory form during the Revolutionary War. In 1781 the confederated thirteen adopted a definite constitution - the Articles of Confederation - which soon proved most unsatisfactory. After only a half-dozen years under this frame of government the present constitution of the United States was formed. In the century since that time many new states have come into the Union, each with its written constitution, and nearly all the states have several times recast their constitutions entirely. Meanwhile the Latin American republics have come into existence and have framed an interminable list of such documents, all more or less based on that of the United States. In Europe, France began in 1791 with her first written constitution, and has followed that with no less than six others. With the gradual dominance of liberal ideas throughout the continent every other nation but Russia has adopted a similar policy, so that at the opening of the twentieth century the land of the tsar is the only civilized country on the globe which is not governed in accordance with the stipulations of a specific constitutional charter. To be sure, a material part of the British constitution is not reduced to statutory form, but much of it is, and the great British colonies, like Canada and Australia, have in the shape of parliamentary enactment each a quite definite organic law.

The political history of Christendom for the last century, then, has consisted largely in the evolution of constitutional government and the fixing of its principles in statutory documents. These documents have many things in common, and at the same time have many differences. Some constitutions include in detail important matters which others omit altogether. Some are elaborate and comprehensive; others are merely sketchy outlines. Some are well adapted to the social conditions and needs from which they have sprung. Others, adopted by imitation from other countries in which success has been evident, are more or less ill-suited to the people to which they are applied, and are in some cases obvious failures. Still, on the whole it is clear that the modern system of goverument involves a fundamental law - a constitution - which shall be quite full and precise, and which, therefore, is best reduced to the form of a definite statute.

The purpose of such fundamental statute - in other words, of a written constitution-is security against abuses on the part of those intrusted with political powerwhether such abuses arise from design, from incompetence, or from inadvertence. Security is found in great part by specific and easily accessible knowledge as to just 
what are the powers which officers of government are entitled to use, and particularly as to the powers forbidden. Of course, to insure protection there must also be provided a means of calling to account officers who may transgress their sphere of authority. Paper restrictions alone are little more than hortatory legislation, and as a rule one cannot rely. on them to restrain average human nature.

The officers of government are merely the agents of a power higher than themselves. This power is found in the last analysis to consist in that portion of the community which has supreme political authority -in other words, whose will is law. In every civilized human community there is such supreme authority somewhere. Some portion of the community of necessity rules the whole, and this portion is the sovereign. Sovereignty - final political supremacy - may belong to a single person, in which case the community is a pure autocracy; to a small number of persons, in which case there is an aristocracy; or to a large number of persons, in which case the community is a political democracy. Autocracies are practically obsolete among civilized men today, that of Russia being the only one on a considerable scale, and even that having in practice no small number of limitations on the theoretical supreme power of the tsar.

Aristocracy and democracy, in the political sense, it will be noticed, are merely relative terms. There is no exact point at which a community ceases to be aristocratic and becomes democratic, and it is quite obvious that a community may be aristocratic as respects a second and at the same time democratic in relation to a third. France under the Orleans monarchy vested supreme political power in some 200,000 voters, while under the second empire there were 7,000,000. More than one of the states of our Union at the outset had suffrage laws so restrictive in character that they were decidedly aristocratic as compared with their present status, although undoubtedly democratic in comparison even with France under Louis Philippe.

An organized political community, independent of external control, is commonly called a state. There is, however, often a confusion of thought arising from the more or less unconscious use of the term "state" in two different senses. These two applications of the term should be sharply distinguished, and the distinction kept always in mind.

In the larger sense the state includes the whole community living in a given territory and subject to the political authority of its government. In the limited sense the state includes only that portion of the community which has political authority over the whole, and whose agent in the exercise of that authority is the government. The state in the larger sense we may, for convenience, call the social state. The other may be called the political state. The members of the social state are all subject to law. The political state creates law and enforces it. Political power belongs to the political state, to be sure, for the protection and welfare of the social state. But in the exercise of that power the political state has no legal superior. Its will is law for all.

In defining and restricting the powers of government the political state at the same time secures itself from the results of the abuse of such power, protects a minority 
of its own membership from oppression by the majority, and also secures the defenseless non-political portion of the social state from like oppression. Political democracy. implies that the political state is a relatively large portion of the social state. The steady extension of suffrage in the states of the American Union has gradually increased the proportional extent of the political state. It goes without saying, however, that even with the adoption of woman suffrage the members of the political state will in a normal society be considerably less than a half of the whole community.

It should be noted that subordinate political communities, in possession, however, of supreme authority over some subjects, are also commonly called states-as those of the American Union, those of the German empire, and those of the Commonwealth of Australia. No adequate scientific term has been suggested as a substitute in such cases. One must bear in mind always in which sense the term is employed-the French state meaning one thing, the state of Illinois quite another.

A constitution is adopted by the political state, but always with the aid of a delegated body (a "convention," it is called in this country), which has greater or less powers in the matter. These powers always include that of drafting a scheme of organic law, and may also include its final enactment. In the latter case the convention is given plenary power.

This latter method is pursued in France under the present constitutional laws. The convention is formed by the union of the two houses of the national legislature in joint session, and the action of this body is final. Thus the constitution of France is amended without the choice of a constituent body ad hoc, and without a popular vote on the amendments drafted.

In the states of the American Union a new constitution is uniformly drawn by a convention chosen for the purpose, but it is usual for enactment to be effected by a direct vote of the people.

A full constitution includes, besides the enacting clause and what may accompany it, usually called the "preamble," four distinct parts.

The first treats of the social state; the second covers a definition and scheme of organization of the political state; the third, by far the most extensive of all, treats of govermment, including its structure, the powers and duties of its branches and of its officers, restriction on the powers of government, and the sanctions by which government is controlled; the fourth includes a mode of changing the constitution-the amending process.

Some of these may be implied, or may be left to the action of the ordinary legislative authorities. Hence it appears that we may have to consider political provisions which are express, or implied-and others which are constitutional or statutory.

\section{THE PREAMBLE}

The only really essential part of a preamble is the enacting clause. This contains the statement by the sovereign authority that the document is made law: "We, the people of the United States . . . . do ordain and establish this Constitution." 
Many preambles contain also other matter, especially such as indicate the purposes of the enactment, and in some cases such as express religious faith. In the preamble to the federal constitution of the United States the purposes are indicated: "In order to form a more perfect union, establish justice, insure domestic tranquillity, provide for the common defense, promote the general welfare, and secure the blessings of liberty to ourselves and our posterity." The preamble of the constitution of the state of Illinois, adopted in 1870, runs as follows: "We, the people of the State of Illinois, grateful to Almighty God for the civil, political and religious liberty which $\mathrm{He}$ hath so long permitted us to enjoy, and looking to Him for a blessing upon our endeavors to secure and transmit the same unimpaired to succeeding generations in order to form a more perfect government, establish justice, insure domestic tranquillity, provide for the common defence, promote the general welfare, and secure the blessings of liberty to ourselves and our posterity, do ordain and establish this constitution for the State of Illinois." Here we have, besides the enacting clause, both the expression of religion and the indication of purposes. The constitutions of Louisiana adopted in 1845, in 1852, and in 1864, had this preamble: "We, the people of the State of Louisiana, do ordain and establish this Constitution." This was the mere enacting clause.

\section{THE SOCIAL STATE}

The extent of the social state is seldom expressly defined in a constitution, as it is plainly enough to be understood from the attendant cireumstances. The Illinois constitution has as its first article a definition of the state boundaries, by which is indicated the area covered by the authority of the state ( $i$. $e$, the political state) of Illinois. The people residing within this area form the social state. The Swiss constitution (Chap. I, Art. I) enumerates the twenty-two eantons of the republic - which in their totality form the confederated social state, as each by itself is the cantonal social state. The German imperial constitution (Art. I) enumerates in like manner the twenty-five states of the empire, and then proceeds (Art.II): "Within this territory the empire shall have the right of legislation according to the provisions of the constitution." Under the war- and treaty-making powers the limits of German jurisdiction have been extended to include Elsass-Lothringen and a number of colonies over sea, thus notably extending the German social state. The Prussian constitution (Art. I) reads: "All parts of the Monarchy in its present extent form the Prussian state territory."

International disputes as to boundaries of course relate to the relative extent of the social states in question, the disputed areas being subject to one or the other legal authority, as the case may be.

The area of the social state is usually divided into convenient portions for governmental purposes. These may be states (as in our own republic), departments (as in France), cantons (as in Switzerland), crown lands (as in Austria), provinces (as in Canada), or they may have still other designations. All are alike in being more practi- 
cable governmental units than the entire nation. They differ only in so far as the organization of the political state differs under different constitutions. There is no common name known to political science by which these primary divisions of the social state may be called. Perhaps for convenience we may indicate them as primary social groups.

These primary groups are farther subdivided, also for governmental convenience, into what may we call secondary groups - counties (in all our states but Louisiana, where they are called parishes), arrondissements - i. e., "districts" - (in France), and the like. In turn, secondary groups may be subdivided into what may be termed minor social groups. With us there are rural groups, towns; municipal groups, cities and villages; special groups, school districts, sanitary districts, and the like. In France the elementary minor social group is the commune, a cluster of which form the canton. Of course there are great varieties in the form and nomenclature of these minor groups.

\section{THE POLITICAL STATE}

The legal qualifications for suffrage mark out the limits of the political state. These qualifications may be embodied in the constitution, or may be left to the discretion of the ordinary law-making power; but in either case they form a most essential element of the organic law. It is the political state which has final authority; which creates and modifies the constitution itself; which directly or indirectly constitutes the personnel of government and enacts ordinary law. It is therefore of prime importance that the membership of this fundamental constituent body of the community should be determined wisely and beyond the possibility of doubt. It would seem, then, that so vital a feature in the commonwealth should be hedged about by every safeguard of the fundamental law. The structure of government itself is surely not more important than the basis on which all government rests.

The French constitution merely requires ${ }^{1}$ that the members of the Chamber of Deputies shall be elected by universal suffrage, details being left to statute. The constitution does not define universal suffrage, but existing law (1874) sufficiently defined it as confined to male French citizens not less than twenty-one years of age. Of these in 1880 there were $9,948,000$, out of a total population of $37,672,048$. Thus in France at that time the political people were at the rate of about 264 to each 1,000 of population - in other words, the political state was 0.264 of the social state.

The German imperial constitution, like that of the French republic, requires that the members of the popular branch of the national legislature shall be elected by universal suffrage, ${ }^{2}$ but leaves the definition to statute. In Germany the electoral law fixes the voting age at twenty-five, and limits the suffrage to the male sex. There were in the empire in $18809,124,000$ qualified voters, out of a total population of $45,234,061$. This made the political people of the empire about 202 to each 1,000 of total population - the political state was 0.202 of the social state.

1 Loi constitutionelle, 25-8 février, 1875, Art. 1.

2 Verfassung des Deulschen Reichs, Art. 120. 
The federal constitution of the United States does not define the qualifications for suffrage in choosing the House of Representatives, but leaves the matter expressly to the several states. ${ }^{3}$ It follows that the states are free to adopt such varying legislation as may seem to them most expedient, and the suffrage laws differ accordingly. Further, the states may embody these laws in their constitutions, as is the case with Illinois, ${ }^{4}$ or may relegate power to the legislature by ordinary statutes. The former, however, is the method preferred. Universal male suffrage, the voting age being twenty-one, prevails in most states. Property or intelligence qualifications are required in a few, and in a small number the sex limitation is waived. On the whole, the political state is not far from a fifth part of the social state.

The organization of the political state is quite as essential as its definition.

In a pure democracy the organization is very simple. The voters gather in one place and need only such officials as may make it possible for the business of the assembly to be conducted in an orderly manner-a chairman, a clerk, and possibly a peace officer to maintain proper decorum. A still more important point of organization, however, is an agreement as to what proportion of the whole number shall, by the common action, be taken as speaking with authority for all. This is usually a majority, although in the Russian village commune unanimity has been required. In the New England town-meeting majority rule has uniformly prevailed.

Large areas and great numbers of people make representative government a necessity, and quite different methods have to be devised for ascertaining the popular will. The political people have to be divided into convenient voting groups and proper devices found for taking the votes and gathering the results. From this necessity have come by gradual evolution our complicated modern election laws, including the Australian ballot and the voting machine. Obviously the debate, which in a pure democracy immediately precedes the vote, must in this other system be disconnected from it, as public organization ean hardly go farther than to ascertain the general will after the people have made up their minds. In elections, however, as in democratic assemblies, it is essential that there be a definite agreement as to the proportion of the total vote which shall rule. This may be a plurality, or a majority, or a fraction larger than a mere majority. In most elections in the states of our republic a plurality suffices to elect a candidate to office. The law of Vermont, however, for instance, requires that if no eandidate for governor has a popular majority then the legislature in joint session shall choose a governor from the highest three candidates on the list. $^{5}$ Rhode Island and New Hampshire have had similar provisions. In California certain questions, such as that of the public ownership of street traction lines in cities, are determined by a vote of the people in the locality concerned, and the proposition to be carried must have two-thirds of all the votes cast on the subject.

But the most vital question relating to the organization of the political state goes

3 United States Constitution, Art. I, sec. $2, \S 1$.

5 Constitution of Vermont, Amendments, Art. IX.

4 Constitution of 1870 , Art. VII. 
much deeper than these matters, which after all relate in the main to convenience, and which may be readjusted from time to time without material disturbance. Voting groups and administrative groups may easily be ephemeral. But in each of the social groups above noted there is a corresponding political group, and the radical differentiation of state structures is based on the differences in the powers and status of these political groups. Are the primary groups organized merely for convenience of administration and for convenience of gathering the popular will? In this case they are wholly subordinate to the central government; their existence and functions are statutory. Or are they themselves, as groups, sharers in the supreme authority, the sovereign power, which is at the basis of the state existence? In this case their existence and functions are constitutional; the constitution itself cannot be altered without their consent.

These give the so-called unitary and federal organizations of the political and social state - of the political state as governing, of the social state as governed.

Of the unitary system France is perhaps the best type. The primary groupsthe departments - are statutory in their origin and status, and are subject at any time to change at the hands of the central legislature by the ordinary process of legislation.

Still more significant than this is the fact that the departments as such have no voice in the process of constitutional amendment. Change in the organic law is effected in France by a majority vote of a joint assembly of the two houses of the national legislature. The deputies - 584 in number - are chosen by a direct vote of the people. Each arrondissement has one deputy, and those with a population exceeding 100,000 are divided into two or more districts, each having one deputy. Under the method of scrutin de liste which was in force from 1871 to 1876 , and from 1885 to 1889 , all the deputies from a department were chosen on a general ticket. But in either case, whether the general-ticket plan or the single-district plan is followed, the deputies are chosen directly by the political people, and are in no real sense representatives of the departments as such. The senators-300 in number - are chosen in the departments by a sort of electoral college, the members of which are the deputies from the departments, the departmental and arrondissement councilors, and representatives from the communes chosen by the communal councils. This last element is by far the most numerous-considerably exceeding all the others combined, so that the senators really are chosen by the communes. They therefore are not really departmental representatives; they have a fixed term and are paid from the national treasury, like United States senators. The constitution is amended, therefore, by an assembly whose members represent the people as a whole, an assembly a majority of which stands for a majority of the French political people taken in a mass.

This is in principle by no means unlike the system under the second empire. Constitutional revision was then enacted by a direct vote of the electorate. The only difference under the present method is that the people may be said now to vote 
indirectly instead of directly on such questions. In either case it is a majority of the whole political people of France which exercises ultimate political authority.

In a state organized on the federal plan, like the United States, the system is radically different. The states, in external aspect much like the French departments, are in fact essentially diverse from them. The test is the enacting of amendments to the constitution. The people are sovereign, we say, and their will is law. By that we mean the political people, to be sure, but not taken in mass, as in France, so that, for instance, a majority of the whole people may adopt an amendment. In enacting constitutional amendments the people are taken by primary groups - states - and a certain proportion of the states is essential to enact, quite irrespective of the popular vote. This is equivalent to saying that sovereignty belongs to the states, rather than to the people of the whole republic in the aggregate. The federal constitution of the United States was originally adopted by the states, has been successively amended by the states, and can be legally abrogated or exchanged for a totally new one only by the states. In other words, it is the will of the states which is the supreme law of the whole republic. This is the essence of the federal system. And in a system in which the states are thus supreme we may well expect that they will reserve carefully to themselves many essential powers, and delegate to the federal government only such as experience has proven to be thoroughly necessary. . In France the structure and all the powers of the departments are a mere emanation from the national legislature, which may at pleasure alter these powers, or resume them, or obliterate the department altogether.

In organizing a federal state it at once becomes essential to determine what proportion of the states shall be decisive in enacting the fundamental law, and what shall be the relative weight of the states in taking such action.

In the United States it is settled that no constitutional change becomes valid without the assent of three-fourths of the states, each state having one vote and only one vote, regardless of size, population, or wealth. ${ }^{6}$ This is equivalent to saying that sovereignty belongs to the states collectively, the voice of three-fourths being taken as expressing the will of the whole. In this sense, then, it is quite true that the states are sovereign; but it does not at all follow that any one state is sovereign in the same sense. Sovereignty lies in the states collectively, not severally.

It is about this point of construction that controversy raged throughout the most of our political history down to the time of the Civil War. The great debate in the Senate between Webster and Hayne, in 1830, centered on the issue of the location of sovereignty in the republic. Each with powerful logic maintained a great truth. Each seems to have missed a fundamental principle, which, being clearly apprehended, would have made their doctrines absolutely identical. Each, therefore, went astray at a certain point, and thus reached a conclusion diametrically opposite to that of the other.

6 U. S. Constitution, Art. V. Even at this point there is one qualification. It is stipulated (U. S. Const., Art. V) that "no state, without its consent, shall be deprived of its equal suffrage in the Senate." This is practically equiva* lent to requiring for a constitutional amendment of this nature a unanimous vote of the states. 
Mr. Webster maintained that the constitution is supreme law over all, and not merely a compact among equals, and that as law it was ordained by the people of the United States in the aggregate. ${ }^{7}$ Mr. Hayne clearly showed ${ }^{8}$ that the people of the United States who formed the constitution were considered only as forming the states respectively; that it was therefore the states which united under the constitution which the states ordained. He thence inferred that the constitution was a compact among sovereigns, which retained full sovereignty, including the power to judge of infractions of the federal organic law.

Mr. Webster erred in holding that the "people" who ordained the constitution were the people in the aggregate; Mr. Hayne was certainly right on that point. But Mr. Hayne erred in inferring that the states that gave their assent to the constitution remained thereafter sovereign in the full sense of the term. In fact, they surrendered final sovereignty to the Union, and, so far as powers delegated to the Union were concerned, became subject to the government of the Union, including the final power of the federal court to interpret "the supreme law of the land." Appeal from the government of the Union in all its branches lay to the Union in its constituent capacity, $i$. e., to the amending power, acting finally by three-fourths of the states. From the decision of three-fourths of the states there can be no appeal but to revolution. Partial sovereignty, if the term is permissible, the states retain in the sense that they have all the residuary powers of government remaining after those delegated to the Union are deducted, and also in that they are equal partners in the sovereign federation, whose will, expressed by the action of three-fourths of their number, is final law for all. It is only in this limited sense that any one state is sovereign. The fallacy of inferring full sovereignty from this partial, or quasi, sovereignty, is obvious. Nullification and secession are revolutionary, and not constitutional, forms of procedure.

In the German federal empire the principle underlying the organization of the political state is essentially the same as in the United States, although the organization differs in form. The states of the empire, like the states of the Union, are sovereign collectively, not severally. The states are directly represented in the Federal Council, a body of fifty-eight members. The members are appointed, not on the principle of equality, as with us, but somewhat in proportion to the importance of the various states. Appointment is by the state governments, tenure is at the will of the appointing power, and votes are determined by instruction from the same authority. Thus it appears that the Federal Council is a permanent convention of states rather than a mere co-ordinate legislative body. The constitution is changed, on recommendation of the Reichstag, by a vote of more than three-fourths of the Federal Council (a proposed change is rejected if there are fourteen adverse votes in the Council). ${ }^{9}$

Practically, then, the federal political state in Germany is organized for the $74,93$.

${ }^{7}$ Congressional Debates, Vol. VI, Part I (1829-30), pp.
8 Ibid., pp. $86,87$.

9 German Imperial Constitution, Art. 78. 
excrcise of sovereign power in the Federal Council, acting by more than three-fourths of the voices; in other words, it requires barely more than three-fourths of the state votes to enact organic law. In the American Union three-fourths suffice. In Germany the states do not vote on the principle of equality. In the American republic this equality prevails.

In the several states of the American Union the political people are defined by state law, usually embodied in the state constitution. Suffrage qualifications vary, but usually include federal citizenship, the age of twenty-one years, the male sex, and a specific period of residence. These qualifications suffice to mark out a portion of the community, rarely exceeding one-fifth in number, who form the political state. Some few states omit the sex qualification, while a few others add restrictions of intelligence or property. In some few states in which these last requirements prevail the existence of a great population, which but a generation ago was servile, results in the placing of legal political power in the hands of a small fraction of the community. ${ }^{10}$

On the power of each state to define for itself the extent of the political state therein the federal constitution lays but one restriction- there must be no deprivation of the right to vote on the ground of "race, color, or previous condition of servitude." " Further, if any qualification is exacted other than federal citizenship, age, and sex, Congress is empowored to reduce the state representation in the House of Representatives proportionally. ${ }^{12}$ The restriction of the fifteenth amendment has thus far been rather easily evaded, and the limitation of representation permitted by the fourteenth amendment Congress has nover yet put in force.

The organization of the political state in all the states of the Union is on the unitary principle, a majority determining action. New constitutions or constitutional amendments are usually referred to popular vote for enactment. At times, however, in several states, a constitutional convention has assumed full power to enact as well as to frame organic law. ${ }^{13}$ The legislature never assumes, and is never granted, such power, and never goes beyond the framing of amendments for submission to the people. In expressing the will of the state on a proposed amendment to the federal constitution, however, the legislature may act with full authority.

In Germany the state governments much more fully represent the sovereign authority of the political people with plenary power. These governments instruct the state representatives in the Federal Council on questions of amendment to the federal

10 The registration of voters in the state of Louisiana in 1888 was 253,557 , of whom there were 125,407 white and 128,150 colored. In March, 1900 (the new constitution by which ignorant and improvident voters were disfranchised was adopted in 1898), the total registration for the state was 130,757 , of whom 125,437 were white and 5,320 colored. In the city of New Orleans in Janunry, 1898, the total registration was 87,240 , of whom 74,133 were white, and 13,107 colored. In the same city in March, 1900, the total was 39,891 , of whom 38,401 were white, and 1,493 colored. It may be added that under the "grandfather clause" 111 colored people were registered.

For the above facts the writer is indebted to Professor J. H. Ficklen, of Tulane University, New Orleans, La.

The population of Louisiana in 1890 was $1,118,587$; in 1900 it was $1,381,62.5$.

$11 \mathrm{U}$. S. Constitution, Amendment XV.

12 Ibid., Amendment XIV, scc. 2.

13 E. g., Illinois Constitution of 1818, Louisiana Constitution of 1898 . 
constitution - amendment to the state constitutions also are usually enacted by the ordinary legislature, and are never referred to popular vote. ${ }^{14}$ The safeguard thrown around Prussian constitutional change lies in the requirement of an absolute affirmative majority in each chamber, and in the further requirement of two separate votes on the question, separated by an interval of three weeks. But after all this plan gives to the Prussian legislature plenary power over the organic law.

The political state is organized for a double purpose. One is to determine the organic law. The other is the enacting of ordinary legislation, the administration of public business, and the due execution of justice. To attain this desired purpose government is created, as the agent, and at the same time as the visible organized form, of the political-state, with the organized electorate behind it. The popular house of the legislature is invariably chosen by the popular electorate, and more or less of the remaining government officials may be directly or indirectly constituted in the same way.

The organization of the state for action on organic law, as we have seen in the case of Germany and Prussia and France, may be identical with governmental organization, the only differences made being those relating to forms of procedure, rather than the construction of the organs by which action is taken, e. g., in France organic law being enacted by the two houses of the legislature sitting together in a single body, while ordinary law is enacted by the concurrent action of the two bodies sitting separately. In the United States, however, various attempts have been made to form a representative organization for this purpose more or less distinct from the government.

The ordinary form which this representative organization takes is the constitutional convention.

This body is chosen by the same electorate which chooses the popular house of the legislature. The purpose of the legislature is to formulate, and usually to enact, ordinary law. The purpose of a convention is usually merely to formulate, rarely to enact, organic law.

The federal constitution of the United States was originally formulated by a convention, and provision is made ${ }^{15}$ that under specified conditions a convention may be called to formulate amendments. The original constitution was adopted by the states through conventions elected for the purpose, and it is provided that amendments may also, at the discretion of Congress, be ratified by conventions. As a matter of fact a federal convention has not been held since that of 1787, although at several times serious attempts have been made looking toward calling one. Amendments to the federal constitution, also, have thus far been ratified by the states through the ordinary legislative bodies. Thus the federal provision for constitutional conventions seems to be a dead letter.

In the states, on the other hand, the constitutional convention is a familiar fact, the 
most of the states having had several. Thus Illinois held constitutional conventions in 1818, in 1847, in 1862, and in 1869-70. New York held conventions in 1776-77, in 1801, in 1821, in 1846, in 1867, and in 1894. It will be noticed how nearly this coincides with Jefferson's view that every generation ought to make a constitution of its own. ${ }^{15 \mathrm{a}}$ In each of these states the first convention enacted the constitution which it formulated, without reference to the electorate, while all formulated since have been referred to popular vote. The constitution framed in 1867 in New York (excepting a single article), and that framed in 1862 in Illinois, were rejected by the electorate. ${ }^{16}$

The Illinois convention of 1862 assumed the peculiar ground that it was the embodiment of the will of the people of the state with plenary power for all purposes, and proceeded to act on a variety of subjects other than framing a constitution. Investigations were set on foot into the operations of the existing state government, several acts of ordinary legislation were adopted, and money to the amount of half a million dollars was appropriated for the relief of wounded Illinois soldiers. These extraordinary powers assumed by this extraordinary convention were undoubtedly null and void. ${ }^{17}$

The convention is a very proper form of organization for framing a complete constitution. It is, however, obviously too cumbersome and expensive a thing for mere amendment, unless, indeed, the amendment in question should be of extraordinary importance. How to provide an organization for this purpose, but distinct from the government, is one of the most difficult problems of political science. In most cases no serious attempt is made to solve it, the power of proposing amendments being given to the legislature. It is not thought that this is a good plan, as the very purpose of the amendment may be further restriction on the legislature-a purpose which that body quite naturally may be reluctant to subserve.

It is clear that in all the methods of initiating action on organic law thus far detailed, at some point the legislature - a branch of government - is permitted to be a factor. This frequently proves an impassable obstacle for measures which the political people may strongly desire. The blocking in the Senate of the United States of a proposition of amendment to the federal constitution looking toward direct election of United States senators is a familiar instance.

American political science has made several experiments in the direction of eliminating, or at least of minimizing, the functions of ordinary legislative bodies as related to action of the state on organic law. Still more has been done in Switzerland in this direction.

The Swiss federal constitution, like the American, provides for proposals of amendment by the federal legislature and ratification by the cantons ("states"). However, there are several other features which are quite unlike the American plan. The Swiss enactment of constitutional amendment is by popular vote throughout the repub-

16 POORE, Charters and Constitutions; vide New York and Illinois. 
lic, and requires at the same time a majority of the entire vote cast and a majority of the cantons. The popular vote on the question in a canton determines the vote of the canton. This dual vote-general and cantonal-takes the place of the American requirement of the legislatures (or conventions) of three-fourths of the states. It may be added that the Swiss method is more flexible than the American, as well as more democratic.

The Swiss federal constitution provides the alternative of a popular initiative in proposing amendments.

Propositions may be made by concurrent vote of the two houses of the federal legislature. ${ }^{18}$ On a question of total revision, if one house of the federal legislature approves and the other disapproves, the question whether the constitution shall be revised is submitted to popular vote throughout the republic. In case the majority of those who vote on the question answer in the affirmative, there is a new election of both branches of the legislature for the purpose of preparing the revision - in other words the legislature thus newly elected acts in the capacity of a constitutional convention to draft the amendments.

Also, whenever 50,000 Swiss voters demand total revision, in like manner the question is submitted to popular vote. If the affirmative carries, there is a new election of both branches of the legislature, as above.

On a question of the desirability of partial revision, no resort is made to the people until after petition by $50,000 \mathrm{Swiss}$ voters.

The petition may be in the form of a general suggestion, or of a completed bill. In the former case, if the two houses of the federal legislature agree, they draft an amendment and submit it for enactment in the usual way. If, however, the two houses do not agree, then the people are asked to vote on the desirability of the suggested revision, and if the majority vote in the affirmative, then it becomes the duty of the legislature to draft it.

The petition for partial revision may be in the form of a completed bill. In case the federal legislature does not agree, that body may draft a bill of its own, or may move to reject the bill of the petitioners, and may submit its own bill or motion to reject along with the petitioners' bill.

These rather complicated provisions of the Swiss constitution are intended to prevent an unfriendly legislature from stifling a measure which the people really desire. There is a curious resemblance between the way in which the popular initiative is thus worked out in Switzerland and the way in which the commons of England came to share in actual legislation. The English commonalty originally merely petitioned the crown for a law to produce a given desired result. If the crown was graciously pleased to grant the petition, it was referred to the crown lawyers to embody in the form of a statute. Not infrequently the people afterward found that such statute really evaded the intent of the petition. After casting about for a remedy, the commons found 
none better than to draw up their petition in the exact form in which they desired it to stand in the statute books, and to insist on the royal assent or rejection without alteration. After a long struggle, the crown reluctantly yielded to this substitute for the old method of petition. Thus was devised the method of legislation by bill. In like manner the Swiss insist that if enough voters agree in demanding a specified amendment to the organic law, they may, if they choose, present their desire in the exact form in which, if adopted, it will stand in the constitution. Then there can be no evasion.

All this is merely one form of that uncompromising democracy which characterizes Switzerland. A few of the Swiss cantons are pure democracies. The rest are representative republics. In both alike, however, the distinction between total and partial revision of the constitution, as well as that of initiation, drafting, and enacting, is quite generally observed. ${ }^{19}$ The procedure is much like that in the American states, with the exception of the considerable extension given to popular initiative. ${ }^{20}$

Enactment of constitutional change in Switzerland is uniformly vested in the people. Such a theory as that according to which some American state conventions assume plenary authority and so proceed to enact into law a proposed constitution is entirely unknown to the Swiss system. Organic law, in other words, is always the product of direct popular legislation. This is not merely a uniformity of practice among the cantons. It is also a requirement of the federal constitution, the sixth article of which provides a federal guaranty of cantonal constitutions on specified conditions, one of which is that such constitutions shall have been ratified by the people.

Another of the conditions precedent to federal guaranty is that the cantonal constitutions may be amended whenever an absolute majority of all the citizens demand it. $^{21}$ This insures the popular initiative on constitutional legislation in all the cantons.

Petition of a specified number of citizens (e. g., 15,000 in Berne) requires a popular vote on the question of amendment involved. If the petition is for total revision, and the popular vote approves it, the formulation (drafting) of the revision is intrusted either to the cantonal legislature (or to the council in the purely democratic cantonsUri, Unterwalden, Glarus, Appenzell) or to a constitutional convention chosen for the purpose. The draft is then submitted to the people for enactment into law.

In several cantons the initiative may also be exercised by a single person or by a small group. In this case there is presented a completed draft of amendment, and it is at once voted upon by the people. This is the rule in the purely democratic cantons.

The constitution of Geneva vests in the cantonal legislature the initiative and the drafting of partial revision, which is then submitted to the people for enactment. ${ }^{22}$ Every fifteen years the question of total revision is submitted to the people. If revi-

19 Pust, pp. $39,40$.

20 Dareste, Vol. I, pp. 516-96; Borgeadd, pp. 258-90.
21 Swiss Federal Constitution, Art. 6 (c).

22 Constitution of Geneva, secs, 152, 153. 
sion is voted, a constitutional convention is elected to make the draft, which also is then decided by popular vote.

Switzerland is eminently democratic. The voters have a close relation to legislation in general. But with reference to the organic law the Swiss idea is not merely that the people are lawmakers, but also that they shall always have an opportunity to express their will as to any given question. The referendum requires the assent of a clear majority of the people in order to make legislation valid. The initiative puts it in the power of a relatively small group--in the pure democracies, of a single citizen--to consult the popular will. The effect can only be to make Swiss cantonal constitutions far more elastic than those of American states. In the latter the initiative either is wholly in the hands of the legislature, or is exercised by the people only on legislative suggestion (save in New York, where the people are consulted regularly every twenty years). As legislatures are elected on a variety of issues, among which constitutional revision is apt to cut a small figure, it is easily possible for the legislature to avoid submitting amendments for which the people would gladly vote.

The Swiss plan permits the ready expression of popular desire. The American plan affords time for more mature deliberation. The Swiss plan makes it easy for the people to change their constitutions whenever they wish. The people of the American states can change their constitutions whenever they very earnestly wish it.

In both Swiss and American plans certain ideas are made prominent.

It is believed that in case of legislation so important as that which changes the fundamental law there should be no doubt that it really expresses the deliberate will of the political state. Hence the care taken to insure deliberation and to ascertain beyond the possibility of doubt what is the actual determination of the state. The various provisions of the two sets of constitutions, Swiss and American, are devised in order to secure these two essentials.

An analysis of their provisions will show this fact. Some are designed to secure delay in action, publicity of propositions of amendment, and full consideration and discussion of such propositions. Examples are the requirement of some American state constitutions that a proposed amendment shall not be acted on by the people until it has passed two successive legislatures; that it shall be entered in full on the journals of both houses; that it shall be published in newspapers a certain time before the election of the second legislature which is to consider it, and a certain time before the election at which the people are to pass upon it. Some or all of these requirements are in force, or have been in force, in a number of states.

Other requirements are intended to secure an incontestable expression of the public will. Such are those which require an especially large majority in the legislative bodies - two-thirds in most of the American states, three-fifths in a few. Such is the requirement of a two-thirds vote in each house of Congress for proposing a federal amendment, and of three-fourths of the states for ratifying the same. Such is the Swiss requirement for ratification by a majority both of the people and of the cantons. 
There would be no particular reason other than those above named for not allowing constitutional legislation to follow in all respects the course of ordinary legislation, were it not for the fact that such a method puts no check on the legislative body - a body which is the agent of the state quite as definitely as are the executive and the courts, and therefore may easily result in making the constitution a nullity. A legislature tends to increase its powers by every means possible. Any agent of the state may become a tyrant. A legislature is quite as dangerous to popular liberties as a king may be-indeed, no fact in the political development of America is more obvious than the growing distrust of legislative bodies. There is no safeguard against this danger unless the constitution be put above the legislature, beyond its reach, and unless it impose on that body specific restrictions which it cannot legally pass.

Chief Justice Marshall, in Marbury vs. Madison (1 Cranch 137), says :

The original and supreme will organizes the government, and assigns to different departments their respective powers. It may either stop here, or establish certain limits not to be transcended by those departments.

The government of the United States is of the latter description. The powers of the legislature are defined and limited; and that those limits may not be mistaken, or forgotten, the Constitution is written. To what purpose are powers limited, and to what purpose is that limitation committed to writing, if these limits may, at any time, be passed by those intended to be restrained? The distinction between a government with limited and unlimited powers is abolished, if those limits do not confine the persons on whom they are imposed, and if acts prohibited and acts allowed are of equal obligation. It is a proposition too plain to be contested, that the Constitution controls any act repugnant to it ; or, that the legislature may not alter the Constitution by an ordinary act.

Between these alternatives there is no middle ground. The Constitution is either a superior paramount law, unchangeable by ordinary means, or it is on a level with ordinary legislative acts, and, like other acts, is alterable when the legislature shall please to alter it.

If the former part of the alternative be true, then a legislative act, contrary to the Constitution, is not law; if the latter part be true, then written constitutions are absurd attempts, on the part of the people, to limit a power in its own nature illimitable.

In this opinion Justice Marshall, with his usual clearness, expresses what perhaps we may call the American doctrine of the relation of constitutional legislation to ordinary legislation. Both, to be sure, are law because they are supposed to represent the will of the state. But the difference in importance is so fundamental that it is held necessary to have a very different procedure in determining and ascertaining the public will, and a very different postulate as to what shall be considered as in fact the will of the people. The collective will of a number of people evidently can rarely be the unanimous voice of all. Hence it is variously conceded that for different purposes it shall be understood that the public will is expressed by a majority of the people, by a plurality of the people, by a majority or plurality of representatives, or by an especial majority either of the people or of their representatives. For ordinary purposes American parliamentary law fixes a quorum of a legislative body as a majority of all the members elected to it, and permits legislation by a mere majority of such quorum. 
For some purposes, especially for financial legislation, no action is valid unless adopted by a majority of all the members. For still others, a two-thirds vote, either of a quorum or of all the members, is required $(e . g .$, in passing a bill over the executive veto). In all these cases legislative action has the force of law because the representative body is held to express the will of the state. The differences in requirement are caused by the view taken in the constitution of the relative importance of different sorts of legislation, and hence of the precise definition of what for various purposes shall be held to constitute the collective will.

Just for this reason, then, the American doctrine requires a more exacting means of expressing the collective will for constitutional legislation than for ordinary legislation. The difference is one of relative importance. The organic law is held to be far more important than any ordinary law.

Further, the American doctrine seeks to safeguard the organic law against legislative encroachment. Hence American constitutions vest in legislatures as little as possible of the power in relation to constitutional amendment. As has been seen, convenience necessitates giving them some share in the process. But the constantly growing tendency has been to minimize that share. In both of these respects, though in a somewhat different way, the Swiss practice follows the American doctrine.

In Germany a different view has been held, and has been to some extent embodied in organic law. Laband insists that ordinary legislative procedure should be sufficient for constitutional modification, for the reason that there is, in his opinion, no essential difference between ordinary and constitutional legislation. Each is law because it is the will of the sovereign. Each is equally with the other the sovereign will. The legislature represents that will and embodies it in law. Hence any legislative action has equal validity with any other.

There is no will in the state superior to that of the sovereign, and it is from his will that both the constitution and laws draw their binding force. . . . . The doctrine that individual laws ought always to be in harmony with the constitution, and that they must not be incompatible with it, is simply a postulate of legislative practice. It is not a legal axiom. Although it appears desirable that the system of public and private laws established by statute shall not be in contradiction with the text of the constitution, the existence of such a contradiction is possible in fact and admissible in law, just as a divergence between the penal, commercial, or civil code and a subsequent special law, is possible. ${ }^{23}$

To one who speaks from the American point of view, this seems to miss some of the essential points. No one will deny that both constitutional and ordinary laws derive binding force from the fact that they embody the will of the state. So far, the two kinds of law are equal-i. e., they are equal as to their source.

The primary difference, however, lies in their relative importance. Organic law is that which the state regards as of graver importance than any other, and hence as something which should be more stable than any other. 
Because of this greater importance, and in order to secure greater stability, it is held that for constitutional law there should be a more exacting definition of what constitutes the will of the state than is requisite for ordinary law.

Further, it is insisted that one vital purpose of organic law is to limit the powers of the legislature - a purpose impossible of attainment if organic law exists at legislative discretion.

None of these considerations come within Laband's theory. His supposed ground of difference between the two kinds of law is non-essential, while he ignores those differences which are essential. His comparison of the relation between organic law and ordinary law, on the one hand, with special legislation, which may be in derogation to civil, commercial, or penal codes, is peculiarly inapt. Such special legislation is merely of the nature of an amendment to those codes, coming not merely from the same source as the codes, but also in the same way and having equal authority. There is no resemblance to the relation of constitutional and ordinary legislation.

Organic law and ordinary law, as considered by American jurisprudence, are fundamentally different not in their source, but in their respective authority. Organic law is supreme. If at any point it conflicts with ordinary law, the latter gives way. Ordinary law which conflicts with the constitution, in short, becomes of no effect. It is not law at all. Both are the will of the state. But the state has also willed that what it regards as the more important shall have precedence. The primacy of organic law is as much the will of the state as is either kind of law itself. The constitution is the supreme law of the land. The supremacy of the constitution is itself a part of the supreme law. ${ }^{24}$ In recognition of this fundamental difference between organic law and ordinary law, and of the danger of permitting the agents of the people created under the constitution to share in constitutional change, American political science has made at least two notable experiments.

The first of these is the council of censors as known in the constitution of Pennsylvania from 1776 to 1790 , and in the constitutions of Vermont from 1777 to 1870.

The first state constitution of Pennsylvania (1776, sec. 47) provided for the election by the people every seven years of a council of censors, one of whose duties should be to order the election of a constitutional convention if in their judgment there should be need of amendment. The censors were to hold office for one year. Under this provision but one council of censors was ever chosen (1783). As that body did not summon a convention, and as the people wished total revision, a convention was called by act of the legislature (1789) for that purpose. The new constitution (1790) abolished the council of censors.

Meanwhile ${ }^{25}$ Vermont adopted a constitution patterned largely after that of Pennsylvania and including the council of censors. Such councils were regularly elected in that state from 1785 to 1869 , being abolished only by the amendments of 
1870. Several conventions were called by the councils, and these conventions adopted a long list of amendments.

The device of a council of censors was not successful. That body seemed to feel that in order to justify its existence it was necessary to propose amendments and to call conventions for their consideration. The plan was too cumbersome and mechanical and altogether too fertile in more or less artificial propositions of change in the constitution.

A second and more successful attempt to separate the representative organization by the state for considering organic law from the corresponding organization for enacting ordinary law is found in the constitutional history of the state of New York.

In the constitution of that state adopted in $\mathbf{1 8 4 6}$ it was provided not merely that the legislature might at any time submit to the people the question whether a convention should be called, but further that once each twenty years, irrespective of legislative action, the people should vote on that question. ${ }^{26}$ In either case, if the vote was in the affirmative it then became the duty of the legislature to provide by law for the election and organization of such convention. By this provision it will be seen that popular initiative in securing amendment was secured without regard to the legislature. In 1894 the constitution of New York was again totally revised, and popular initiative was still further guarded. ${ }^{27}$ Not merely is the popular vote on the question of holding a convention to be taken at twenty-year intervals, but the last vestige of intervention by the legislature in the matter is swept finally away. In case the people vote in the affirmative, the constitution itself provides minutely for the apportionment, election, organization, and procedure of the convention. Thus there is now imbedded in the constitution of New York a complete system for total revision of the constitution of that state beyond the control of the legislature. The people initiate, the convention drafts, the people enact.

The problem of how the people may modify their organic law without the intervention of their governmental agents, who may be deeply interested in preventing such modification, is one of the most difficult in political science. It is hardly solved in the federal constitution of the United States. In the closing debates of the convention of 1787 Colonel Mason, of Virginia, sharply criticised the plan adopted:28 "As the proposing of amendments is in both the modes to depend, in the first immediately, and in the second ultimately, on Congress, no amendments of the proper kind would ever be obtained by the people, if the government should become oppressive, as he verily believed would become the case," The New York plan seems to offer an adequate solution, so far as calling a convention is concerned. But there is no solution yet reached in this country relating to the submission of single amendments, in which case a convention is obviously undesirable. Various methods of popular initiative, on the Swiss plan, have been urged. Possibly in some carefully guarded plan of this

28 Madison's Journal of the Convention, September 15, 
sort, tentatively adopted and perfected by experience, the final solution may be found. A mere copy of the Swiss system would hardly work in so complex, so changing, and so populous a community as that of an American state.

\section{THE GOVERNMENT}

The ordinary organ of the political state is the government, and with this a large part of every constitution is concerned. The provisions on this subject deal with the structure of the government, with the powers and duties of its various officers, and with restrictions placed on them.

\section{STRUCTURE OF GOVERNMENT}

In its most essential outlines governmental structure is marked out in a constitution, details being left to ordinary statute. The extent covered by constitutional provisions differs in the various branches of government, and in various nations. Usually constitutional structure is most nearly complete in relation to the legislature, while great latitude is allowed that body in framing the courts and the administrative branch. The head of the administration is always constitutional, as is commonly the case with the main appellate court.

The legislature in every constitutional state either is a single body directly chosen by the electorate (as in Greece, Servia, Roumania, and virtually in Norway), or, as is usually the case, is bicameral, with a popularly elected house as one of the two chambers. As we have already noted, the political state is organized with direct reference to the choice of legislators. The constitution, besides determining this electoral organization, deals with the number of members in the popular house, with their appointment, their term of office, their prerequisite qualifications, and with the organization of the house as a legislative body.

The number of members is usually determined by statute, but sometimes with a constitutional minimum. This in the United States was originally a requirement that there should be not less than one for ench 30,000 of population. Each state must have at least one, and as the apportionment must be among the states according to population, there naturally will always be more representatives than there are states. ${ }^{29}$

Apportionment, again, is left to statute, as it must change with changing population conditions. Specific conditions of apportionment, however, may be fixed in the constitution. In the United States the apportionment of representatives is to be based jointly on population and on state areas. Each state must have at least one member, the members are assigned to states, the assignment must be in proportion to population. ${ }^{30}$ In France and Germany apportionment is wholly statutory, while in Switzerland it is wholly constitutional. ${ }^{31}$

The term of office is fixed in the constitution. In countries which give the execu-

\footnotetext{
29 United States Constitution, Art. I, sec. 1, § 3; Amendment XIV, sec. 2.

30 Ibid.
}

31 Federal Constitution of Switzerland, Art. 72; Ver fassung des deulschen Reichs, Art. 20; Loi relative d l'organisation des pouvoirs publics, Art. 1. 
tive the power of dissolution, however, the constitutional term is subject at any time to be terminated by such executive action. This is the case in all countries which have cabinet government (e.g., France, Austria, Italy) and in the German empire. In Switzerland the constitutional term of the members of the National Council may be terminated in order that a new Council may be chosen to formulate a constitutional amendment demanded by popular vote..$^{32}$

Qualifications are fixed for members of the House in the constitution of the United States, ${ }^{33}$ and in that of Switzerland (Art. 75), but in other European lands are usually left to statute.

The organization of the House is specifically left to that body in the constitution of the United States, ${ }^{34}$ and is impliedly so left in most European constitutions. In Switzerland the power is left to the Council under some specific restrictions (Art. 78).

The structure of the other house of the bicameral national legislature is far more definitely fixed in the constitution. In some constitutions the number of members is specified - in the United States two for each state, in Switzerland two for each canton, in France 300 members, in Germany 58, in the Netherlands 50. In Belgium the number is varying, being dependent on population, but is always equal to half the number in the lower house. In Norway the legislature (the Storthing) is chosen indirectly. There are $11+$ members, and on assembling they divide into two houses, onefourth forming the Lagthing and the remaining three-fourths the Odelsthing. The Swedish upper house contains 150 members, elected indirectly. In all these countries the members are elected, or appointed, for limited terms.

Other nations have constructed an upper house modeled somewhat after the British House of Lords. The Italian Senate contains the princes of the royal family of full age, and an indefinite number of senators appointed by the king for life. The conditions of appointment are the age of forty years, the filling of high office, distinction in some public pursuit, or wealth.

The Prussian upper house consists of members appointed by the crown, either for life or on hereditary tenure, and a few elected members. ${ }^{35}$ The Austrian House of Lords consists of princes of the imperial family, hereditary peers, life peers appointed by the emperor, and seventeen high ecclesiastics who hold the peerage by virtue of their sees. The Hungarian House of Magnates is somewhat similar in structure, but includes a much larger number of ecclesiastics (fifty-four-twelve of these being representatives of Protestant bodies), and also some life peers elected by the upper house itself, and three representatives from Croatia - Slavonia.

The organization of the upper house, like that of the lower, is usually left to the honse itself. In the United States the presidency of the Senate is fixed in the vicepresident ${ }^{36}$ and in Germany the imperial chancellor presides in the Federal Council. ${ }^{37}$ The French Senate elects its own president and other officers. ${ }^{38}$ With a very few



32 Federal Constitution of Switzerland, Art. 120.

33 A rt. I, sec. 2, § 2.

35 Prussian Constitution, Arts. 65-9.

36 U. S: Constitution, Art. I, sec. $3, \S 4$.

37 Reichsverfassung, Art. 15.

38 Loi constitutionelle, 16 juillet 1875 , Art. 11 . 
exceptions (e.g., in Prussia and Hungary, as above noted), the number and personnel of membership in the upper house are independent of statute or of the house itself.

Details of organization of both houses are statutory-the number, duties, and compensation of minor officers, for instance.

The structure of the executive, so far as the chief of the administration is concerned, is uniformly constitutional. The great body of administrative subordinates, however, are provided by statute.

There are three types of executive known to modern constitutional government.

In the United States executive power is vested in a single person, who has a fixed tenure, is supreme over his subordinates, and is independent of the legislature. The president is chosen for a four years' term by electors, who in turn are appointed by the states, in a manner left to the discretion of their legislature. ${ }^{39}$ His large powers of appointment and removal give him the actual direction of administration. Of course, his policies cannot be carried out with entire success unless he has the co-operation of the legislature. Still, on the other hand, he cannot in any practical way be controlled by that body. This we may call the unitary, or presidential, system. The somewhat definite constitutional provisions are supplementer by exhaustive statutory legislation covering, in the first place, details as to the procedure of the electors and a mode of settling disputes over the election, and, in the second place, providing for the numerous executive departments and officials - civil service, army, and navy.

The executive of the German empire is on the presidential system. The emperor holds by a tenure independent of the legislature (the king of Prussia is ipso facto German emperor), and is supreme over his administrative departments. ${ }^{40}$ The military and naval service in Germany are much more definitely fixed in the constitution than is the case in the United States, ${ }^{41}$ but even here much statutory legislation is necessary. The imperial civil service is far less extensive than in the United States, as German policy involves carrying out imperial law by means of state authorities. Customs and internal revenue, for instance, are collected by state officials. The imperial service, therefore, comprises little more than the central departments at Berlin and the diplomatic and consular service abroad.

The second form of executive structure, quite common in Europe, is dual, vesting the main dignity and continuity of office in a single person, and the main executive power in a group of persons - the cabinet-whose members are usually heads of executive departments. The cabinet, while appointed by the head of the state, is in fact responsible to the legislature and subject therefore to legislative control. This is the so-called cabinet system of government, which originated in England. It has been adopted in France, Italy, Spain, Portugal, Belgium, Holland, Austria, Hungary, and in a modified form in some other countries. The constitution goes no farther than to define the relation

39 U.S. Constitution, Art. II, sec. 1; Amendment XII.

41 Ibid., Arts. 53, 57-68.

40 Verfassung des Deutschen Reichs, Art. 11. 
of the head of the state and the cabinet to each other and to the legislature. The specific cabinet departments, with all their internal structure, are entirely statutory.

The head of the state, on the other hand, is defined by the constitution. In all but France the form is monarchical (e.g., Constitution of Italy, Art. II: "The throne is hereditary according to the Salic law"), with hereditary succession. In France the president is elected for a seven-years' term by the National Assembly-i.e., the two houses of the legislature in joint session. ${ }^{42}$ His status is exactly that of a constitutional monarch with a responsible ministry. ${ }^{43}$

The curious plan of a ministry which must have a parliamentary majority behind it, the product of peculiar conditions in English constitutional development, has thus been transplanted to the continent. It can hardly be called an unmixed success.

In the states of the American Union the presidential, or unitary, plan of executive structure is apparently followed in all cases. In fact, however, this is far from accurate. The governor is nominally head of the state, but the real executive powers are distributed among various quite independent offices. ${ }^{4}$ The governor is elected by the people, and holds for a fixed term, being thus independent of the legislature. Heads of administrative departments corresponding to those held by members of the federal cabinet are also in nearly all cases elected by the people for fixed terms, and thus are independent both of governor and legislature. The legislature, on the other hand, is independent of the executive, as both houses hold for a fixed term, and the governor has no power of dissolution. This is a nondescript plan, which in a national government would be sure to fail. In a state administration it makes less difference, however, as there is less need of a coherent state policy and less room for individual differences of judgment in plans of administration. In the states the center of political power is in the legislature, while in the federal government the legislature and the executive divide power and responsibility rather equally. The statutory part of the administration in the states is very extensive. Besides the constitutional departments, such as the state treasury, that of secretary of state, attorney-general, auditor, and perhaps superintendent of public instruction, and state engineer and surveyor, there is usually a number of departments and institutions, generally administered by boards, and all created by statute. The whole structure of county and municipal government, with the public schools and the state militia, both military and naval, are also statutory, under certain constitutional restrictions. In some of these cases the statute vests the appointing power in the governor. On the whole, however, the constitution of a state is apt to provide little more than a skeleton of administrative structure, leaving it to be filled in by the legislature.

The third sort of executive known to modern constitutional states is that existing in the Swiss federal government-that of an executive council, or what might be called the plural system, as compared with the unitary executive of the United States and the dual executive of France. The Swiss constitution (Arts. 95-8) provides an 
executive of seven persons, chosen for a three-year term by the two houses of the federal legislature in joint session. The president of the confederation is also chosen by the federal legislature in like manner, being selected from the council of seven for a term of one year, and being ineligible for the year next ensuing. The president is little more than chairman of the council. The seven members are heads of executive departments (Art. 103), but no executive decision is made except by the council as a whole.

This plan of a group executive is virtually the same as that of France under the directory (1795-99), and is naturally such as might be expected in a nation which has reason to dread monarchy. It differs from the cabinet system in the lack of administrative continuity which is supplied by the head of the state (whether king or president), and also by its tenure for a fixed term. The system of parliamentary responsibility might perhaps be applied to the group executive, but it would not be so convenient as in a state with a permanent, or relatively permanent, head.

Details of structure, civil and military, are supplied in Switzerland, as in other countries, by statutory enactment.

The structure of the courts is more largely left to statute in all constitutional states than is the case with either of the other great branches of government.

In France the whole judicial system is statutory - the constitutional laws are silent on the subject, save only in vesting some judicial power in the Senate. ${ }^{45}$ In the United States the federal constitution ordains that there shall be one supreme court, ${ }^{46}$ but leaves to statute the whole matter of the structure of that court and of all inferior courts, save only the provision of the tenure by good behavior and of appointment by the president. ${ }^{47}$ In point of fact, Congress has provided for an elaborate system of federal courts. ${ }^{48}$ The Senate is by the constitution a court of impeachment. The German imperial constitution vests certain judicial power in the Federal Council. ${ }^{49}$ The whole remaining judicial structure is statutory. Unlike the American system, there is not a dual judiciary in Germany, however. The courts are created by federal law and administer federal law, but are appointed in the several states of the empire by the state authorities, and are in a large sense staté courts. But they are wholly statutory. Thus the German judiciary in its constitutional basis is almost exactly like that of France, notwithstanding the federal structure of the empire and the unitary structure of the republic.

The Swiss constitution, like that of the United States, provides for one federal court, ${ }^{50}$ but leaves to statute "the organization by the federal court and of its sections, the number of judges and alternates, their term of office, and their salary." ${ }_{01}$ The judges, like the executive council, are chosen by the two houses of the legislature in joint session. $^{52}$ Cantonal courts, again, as is the case in the United States, and in this respect differing widely from the German system, are regulated exclusively by cantonal law.

45 Loi constitutionelle, 16 juillet 1875, Art. 12 .

46 U. S. Constitution, Art. III, sec. 1.

47 Ibid., Art. II, sec. 2, \$2; Art. III, sec. 1.

48 See especially the judiciary acts of 1789 , of 1867 , and of 1891 .
${ }^{49}$ Arts. 74, 76, 79.

50 Swiss Constitution, Arts, 106-9.

51 Ibid., Art. 107.

52 Ibid, 
The Italian constitution (Arts. 68-73) leaves the structure of the courts to statute. under a few limitations. The judges are appointed by the crown, and after a probationary term of three years their term is permanent (Art. 69).

The Belgian constitution provides for one appellate court (Art. 95), as is the case in Switzerland and the United States, and also for three intermediate appellate courts (Art. 104). All judges are appointed by the crown (Art. 99), and hold on life tenure (Art. 100). It is also provided (ibid.) that "the removal of a judge from one place to another can take place only by a new appointment and with his consent." The absence of such a provision in the Italian constitution has led to frequent transfer of judges, and thus has tended to break down the independence of the judiciary by subordinating it to the political branch of government. ${ }^{53}$ Aside from these and a few other more or less unimportant limitations, the legislature in Belgium is free to fashion courts at will (Art. 94).

In the United States the structure of the state judiciary is independent of federal legislation, and is largely regulated by the state constitutions. Indeed, these documents are concerned with the structure of the courts much more in detail than is the case with the federal constitution, and successive constitutions in the same state nearly always reconstruct judicial structure. The lawyers, who are apt to form an influential part of a constitutional convention, are keen to detect defects in the courts and are eager to remedy them. Thus in the New York convention of 1821 a new judiciary article (Art. V) was adopted, by which existing courts were abolished, and an entirely new system was created. Circuit courts were interposed between the county courts and the supreme court, and the legislature was authorized to vest equity powers in any of the subordinate courts, "subject to the appellate jurisdiction of the chancellor" (Art. $\mathrm{V}$, sec. 5). ${ }^{54}$ Again in 1846 a constitutional convention met in Albany and adopted a new constitution. The article on the judiciary (Art. VI) made a sweeping reform of the courts. The old court for the trial of impeachments and for the correction of errors, the highest appellate court of the state, to which appeals lay both from the supreme court and from the court of the chancellor, consisted of the state senate, the judges of the supreme court, and the chancellor. ${ }^{55}$ This was preserved by the convention of 1821 (Art. V, sec. 1). The convention of 1846 relegated the trial of impeachments to the senate, created a new court of appeals distinct from the legislative branch of the government, abolished the circuit courts, divided the supreme court into branches, which were to hold court in separate districts of the state, abolished the court of chancery, vested equity jurisdiction in the courts of law, made all the supreme-court judges and the judges of the court of appeals elective, and made the term of office eight years. The next constitutional convention of New York met in 1867. In 1869 their plan for a new constitution was submitted to the people by separate articles, and the only one ratified was that on the judiciary (Art. VI). By this article the term of

53 LowelL, Governments and Parties, Vol. I, pp. 177, 178.

54 See Hamond, Political History of New York, Vol.

55 Constitution of 1777, Art. XXXII. II, pp. 52-64. 
office of judges, both of the court of appeals and of the supreme court, was extended to fourteen years, and the term of the county judge was extended from four years to six years. The court of appeals was far behind in its docket, and to relieve the situation a commission of appeal was created, authorized to act in lieu of the court of appeals in all cases which might be pending on the first of January, 1869. Various other changes were also effected. In 1894 New York again held a constitutional convention, and the new constitution was adopted by vote of the people. Again one of its essential articles was that which reconstructed the judiciary (Art. VI).

The constitutional changes which the successive conventions of New York have embodied in the judiciary system of that state have been given somewhat in detail as illustrating the minuteness with which state constitutions treat judiciary structure. This is in rather sharp contrast with the sparing touch on the subject in national constitutions. Still, even with the detail of constitutional provisions, much is necessarily left to state legislation, and accordingly every convention is followed by a judiciary statute full of elaboration.

Taking constitutional structure of government as a whole, it is plain.that what each nation regards as most imperative is therein contained. All else is left to statute. If the legislatures abuse the powers confided to them, there may be amendments taking over such powers and fixing the desired structure in the constitution. The legislature, as intrusted with a vast field of law-making power, is the most vital part of the government, and accordingly its structure is worked out in all constitutions with great care and attention to detail. Still the statutory powers with reference to the legislature are very considerable - as witness apportionment and election laws. However, after all no statutes can affect the essence of legislative structure.

At the other end of the scale are the courts. Modern political development has turned very little on their structure, being pretty well content with the judicial system which has grown up through the ages. Judicial independence from other departments of government has been the main thing sought, and this is generally secured by fixity of tenure; in most of the states in the American Union the same end is attained by an elective judiciary. Nearly the whole field of judicial structure, however, save only in our states, is left to statute.

Midway between the legislature and the courts, in point of constitutional exactness of treatment, lies the executive. The fundamental principles, the structure of the supreme executive authority-these are necessarily constitutional. But by far the greater mass of administrative organization lies in the field of statutory creation.

A constitution can be given effect, and be put in force as a living thing, only by a long series of comprehensive statutes. When the first federal Congress under the present constitution met, it was at once confronted with the necessity of providing by law for the machinery of government of which only the bare outlines were in existence. By successive acts in 1789 were created the first three executive departments - those of state, treasury, and war. In later years the remaining departments, as they now 
exist with their various bureaus and officials, have been established by a series of statutes. In like manner the judiciary act of 1789 created the courts, which subsequent statutes have only modified in details.

In the states of our republic structure is far more definitely fixed in the constitution. Still, there is left to the legislature a large field of power over structure. The difference between states and the United States lies mainly in the fact that the former may much more easily amend their constitutions than the latter, and hence they have repeatedly given expression to their discontent by embodying in organic law reorganizations which constantly tend to become more elaborate. The first constitution of New York (1777), omitting the preamble, is comprised in about seven pages (of Poore's collection), that of 1821 in nine pages, that of 1846 in seventeen pages.

\section{GOVERNMENTAL POWERS AND DUTIES}

The powers and duties of the different branches of government, including the special rights and privileges of the various officials, are partly stipulated in the constitution, partly vested by statute. What are deemed the most essential are constitutionai, while the legislature is left large discretion in assigning further functions to the executive, and in distributing judicial powers among the several courts.

A careful distinction is made between powers and duties. The exercise of the former is discretionary, that of the latter is mandatory. Thus the president may convene Congress in extraordinary session, ${ }^{56}$ but he shall take care that the laws be fully executed. ${ }^{57}$

Governmental powers are in a modern constitution distributed among various branches of government, it being thought dangerous to the public safety for one branch to exercise more than a definite portion of public functions. The three great branches into which governments have evolved are the legislature, which is intrusted with the making of statutes; the executive, which administers the laws, whether of the constitution or of the statutes; and the courts, which interpret and apply law. It is the implied theory of the federal constitution of the United States that these functions are kept separate. In the constitution of Illinois there is a specific stipulation: "The powers of the government of this state are divided into three distinct departments - the legislative, executive, and judicial; and no person, or collection of persons, being one of these departments, shall exercise any power properly belonging to either of the others, except as hereinafter expressly directed or permitted." 58

It is impracticable to make such a separation of powers absolute. There is always a margin of function which of necessity overlaps two or more branches. But the old maxim, De minimis lex non curcat, applies to constitutions as well as to other forms of law. As long as the three great branches of government are measurably separate and independent in structure, and as long as they keep on the whole to different spheres of work, the interests of the people do not suffer. It is the ancient 
conception of kingship, whereby the king was lawgiver, and law administrator, and at the same time final judge in interpreting law and administering justice under it, for which modern constitutions seek a substitute.

Another vital point in a constitution relates to the doctrine of residuary powers. By a constitution powers may be granted to the various branches of government. These are not usually when taken together the sum total of the powers which the sovereign authority - the political state - may exercise, but are only a part of them. What becomes of the remainder? They may be reserved by the political state from any of its governmental agencies, or they may be vested in some one of their forms. It is this remainder of powers which is known to political science as the residuary powers of government. In the British state the doctrine is that these residuary powers belong to the crown -i.e., that the crown has all powers not forbidden by act of Parliament, or not vested by Parliament in some other branch of government. In the United States the residuary powers belong to the states. ${ }^{59}$ The states in turn in their constitutions have limited their governments in various ways, and then leave the final residuary powers to their legislatures. In other words, the constitutional doctrine as to all branches of the federal government is that they have only such powers as are granted, expressly or by implication, in the constitution; while the principle of interpretation of state constitutions is that these documents do not contain a grant of powers to all departments, like the federal constitution - that they indeed grant powers to the executive and to the courts, but, on the other hand, limit the powers of the legislature; and hence that a state legislature may do anything not forbidden either by the federal constitution or by the state constitution. ${ }^{60}$ In other words, as has been said, in the states final residuary powers are in the state legislatures.

While it is true that in the United States residuary powers belong to the states, and in each state to the legislature thereof, yet it must be remembered that this doctrine applies only to the states. When it comes to the territories a very different doctrine prevails. These are the property of the United States as a whole, and full powers for legislation are confided to Congress. ${ }^{61}$ Thus the doctrine of the power of Congress over territories is analogous to that of the powers of the British crownCongress may do anything not forbidden ad hoc by the constitution. The enumeration of prohibitions on Congress as relates to territories is not long - possibly the personal immunities guaranteed in the first eight amendments, certainly the immunity. against the legal status of slavery ${ }^{62}$ and the political immunity as to suffrage. ${ }^{63}$ In short, regiduary powers of government over territories belong to Congress, and in fact they cover nearly the whole governmental field. ${ }^{6+}$

This is quite the reverse of the doctrine of the Dominion of Canada, in which federation the provinces have only delegated powers, while residuary powers are in

59 U. S. Constitution, Amendment X.

60 E. g., Wilson vs. Board of Trustees, 133 Ill. 448; also cases there eited.

61 U. S. Constitution, Art. IV, sec. 3, \$2.
62 Ibid., Amendment X11I.

63 Ibia., Amendment XV.

64 Am. Ins. Co. vs. Canter, 1 Pet. 511, 542; Mormon Chureh vs. U. S., 136 U.S. 1, and cases cited. 
the federal government. This practically makes less difference than might appear, however, as the delegation is very specific.

Powers being granted and duties imposed on the various branches of government, it then becomes necessary for a constitution to provide some sanction in case of misuse of powers or violation of duty. This properly assumes two forms. There may be a criminal violation of duty - either omission to perform some mandate of the constitution, or trespass on powers constitutionally withheld-or performance of duty may be such as, without being illegal, still encounters disapproval on the part of the people or of other legal superiors.

In order to meet these cases constitutions make a variety of provisions.

Great officers of state in the United States, "the President, Vice-President, and all civil officers of the United States," are tried by the Senate siting as a court. A similar practice is followed in most of the states; in Nebraska the impeachment is brought by the two houses of the legislature in joint session, and is tried by the supreme court, unless a justice of the supreme court is impeached, in which case the trial is before a court of impeachment consisting of all the district judges. ${ }^{66}$ This process has been borrowed from England. Judgment in case of conviction under impeachment does not extend beyond removal from office - which may be made permanent in the shape of disqualification to hold office thereafter. After removal from office the convicted officer, if his offense is otherwise punishable under the statutes, is liable to the ordinary criminal process.

Impeachment is a clumsy proceeding, and resort to it is rarely made. In place of action under it inferior officers in case of malfeasance may be removed in a way provided by law, and are subject to indictment, trial, and conviction like private citizens.

To meet the contingency of unsatisfactory performance of duty two provisions are usually made. Tenure of office is for a fixed term, not too long, so that in case of dissatisfaction reappointment or re-election may be withheld, and the power of removal may be used. Of course, in such cases, there is no criminal liability. The British method of changing a ministry puts it in the power of the House of Commons at any time to displace an unsatisfactory cabinet. The American plan substitutes for this a short fixed term-four years for the executive, six years for the upper house of .Congress, two years for the lower house.

\section{GOVERNMENTAL RESTRICTIONS}

A fundamental part of an American constitution is a series of prohibitions on government-the greater part of which are usually grouped as a so-called "bill of rights." Every state in the Union has an article in its organic law devoted to this subject, and the federal constitution was strongly opposed at the outset in many of the states because it was lacking this body of stipulations. The British bill of rights was 
in its origin a series of restrictions on the crown, but in American constitutions the inhibitions lie against all branches of the government, including the legislature.

Rights which belong to individual members of the state as against the government are commonly called immunities. They are of two classes-civil rights, which belong to all members of the social state, and political rights, which belong usually only to members of the political state, although they are sometimes extended in part to some others. Political rights are the right of suffrage, by which membership in the political state is constituted, and the right to hold office. In our states women do not usually have the right to vote, although they are seldom constitutionally debarred from holding office.

Civil rights, or immunities, are those which belong to all members of the social state, as against government. They cover the field of civil liberty, and as a rule include the various exemptions from governmental intrusion which have been extorted from tyrannical governments through long ages of political and social strife. Such are the freedom of speech and of the press, religious liberty, the right of trial by jury, the habeas corpus, and the numerous other safeguards thrown around a member of the state who is accused of crime.

It is essential to notice that these immunities after all have their limits - the limit as a rule being the point at which the exercise of the right would unduly injure the state or any of its individual members. Thus libel laws are framed to repress freedom of speech which degenerates into license; thus the privilege of the writ of habeas corpus may be suspended when there is a pressing emergency of war; thus martial law may displace the orderly operation of civil judge and jury. This limitation of civil liberty is well expressed in the Illinois Bill of Rights: ". . . . but the liberty of conscience hereby secured shall not be construed to dispense with oatlis or affirmations, excuse acts of licentiousness, or justify practices inconsistent with the peace and safety of the State;" "Every person may freely speak, write, and publish on all subjects, being responsible for the abuse of that liberty." 68

Besides the general inhibitions against government found in the "bill of rights," there are invariably in American constitutions special inhibitions against the acts of particular branches of the government, especially the legislature. Such in the federal constitution are prohibitions on Congress. ${ }^{69}$ State constitutions not merely contain considerable lists of such specific prohibitions on the powers of the legislature, but, as has been intimated, the whole document must be construed as limiting the legislative power. One of the most striking facts in the political and constitutional history of our states is the growing distrust of representative assemblies, as evidenced by the steady increase of restrictions on these bodies in successive state constitutions. At the outset the states seemed to feel that there could be no more political troubles, seeing that they had freed themselves from the royal governor, who had been the object of all their civic animosities. But presently the people became aware that their own

\footnotetext{
67 Illinois Constitution, Art. II, sec. 3.
} 
representatives would bear watching, and were inclined to misuse their powers. The New York constitution of 1777 vested legislative power in the assembly of the state of New York, with scarcely any express restrictions. The constitution of 1821 added an article (Art. VII), in fourteen sections, embodying a bill of rights. Besides the usual provisions for civil liberty, there were sections requiring a two-thirds vote by the legislature for certain classes of acts, such as appropriating public money for private purposes, or creating or renewing corporations (sec. 9); requiring appropriation of money from the public land fund to be devoted to common schools; limiting the legislative power over the state canals and salt springs (sec. 10); forbidding the authorization of lotteries (sec. 11). In the constitution of 1846 the "bill of rights" (Art. I) contained eighteen sections, and besides there are entire new articles - one (Art. VII) devoted to restriction on the lawmaking power with reference to a long list of matters of finance, one (Art. VIII) containing like restrictions as to corporations, and one (Art. IX) as to the school fund. The constitution of 1894 re-enacted in Art. I the bill of rights of 1846 with few changes, and provided a considerable addition to the already long list of restrictions on the powers of the legislature.

In a federal state there is a dual government, and hence there is a dual bill of rights; in other words, the member of the state has constitutional immunities against the federal government and a second set of constitutional immunities against the states. These are both found in the federal constitution of the United States.

In the original constitution few restrictions were placed on government, the theory of the document being that it was a delegation of powers, that the federal government could use no others, and hence that a bill of rights was needless. In the field of powers granted some limitations were placed. Thus the writ of habeas corpus could be suspended, but only in case of war $;^{70}$ the power of criminal legislation, scanty at best, was restricted from covering bills of attainder or ex post facto laws; ${ }^{71}$ the taxing power was put under the three restrictions of uniformity, for indirect taxes ${ }^{72}$ - proportion to population, for direct taxes ${ }^{73}$ - and absolute prohibition, for duties on exports from states $;^{74}$ the commerce power was restricted by the requirement of equity as among states $;^{75}$ the spending power was put under certain methods $;^{i 6}$ and titles of nobility were prohibited..$^{77}$ Again, the judicial power was limited in criminal trials to the use of juries, ${ }^{78}$ and in treason trials by a fixed definition of the crime, by set rules of evidence, and by a restriction in penalty. ${ }^{79}$ There were also sundry other restrictions implied at various points.

Strong demand on the part of ratifying states led to still further restrictions on the powers of the federal government, found in the first ten amendments. These are general and sweeping in form, but it must be noted that they do not apply to the states at all, but only to the federal government. This has been uniformly held by the Supreme Court, and in a long list of cases. ${ }^{80}$ The federal judicial power was fur-

\footnotetext{
70 Art. I, sec. $9, \S 2$.

72 Ibid., sec. 8, \& 1.

74 Ibid., 85 .
}



76 Ibid., $\$ 7$.

77 Ibid., \&8.

78 Art. III, sec. $2, \S 3$.

${ }^{80}$ E. $g$.,Twitchell vs. The Commonwealth, 7 Wallace 321. 
ther limited by the eleventh amendment, and the thirteenth and fifteenth laid further inhibitions on the federal government in all branches.

This list of specified immunities, with the further doctrine that the federal govermment has no powers but those granted, either expressly or.by limitation, covers the field of civil and political liberty which the federal government may not enter. Some are for the protection of the person, some for the protection of property.

Immunities against states are found in the tenth section of Art. I of the constitution. These inhibitions, it will be seen, are of two sorts - those which are unqualified, $i$. $e$, things which states are forbidden to do under any circumstances at all, as, for example, to coin money, or pass a bill of attainder $(\S 1)$; and those which are qualified, $i$. e, things which states are forbidden to do except under specified conditions (such conditions, in fact, being the consent of Congress), as in paragraphs 2 and 3 of the section. Immunities against Congress, it may be said in passing, are also of these two kinds, qualified and unqualified. Other immunities against states are found in the last three amendments - the war amendments - which were avowedly intended to secure civil and political immunities for the freedmen.

A still further class of immunities lies in implications from the powers of the federal government. If a power is granted to Congress which from its nature can be used by only one of the two parts of our federal system, $i$. e, either by the federal government or by the states, but not by both simultaneously, then the exercise of that power by Congress must be understood as excluding the states from the field thus occupied. An example will be found in the power of Congress to make "uniform laws on the subject of bankruptcies throughout the United States." si So far as Congress legislates on this subject, state legislation is debarred. But from time to time Congress has repealed its bankruptcy laws, whereupon state power over the subject at once revives. ${ }^{82}$ These implied immunities against states are determined by the Supreme Court in a long series of decisions, covering in detail a very wide range of subjects.

The express immunities above enumerated, and the implied immunities, as laid down by the Supreme Court, cover the whole field of civil and political liberty on which the states must not trespass. Some are for the protection of the person, some for the protection of property.

The immunities which belong to citizens of the United States as such are all in one or the other of these two classes. Some of them are identical - as the prohibition to enact an ex post facto law, which lies both against Congress and against the states. Others are quite distinct. The states may not pass a law impairing the obligation of a contract, but no such immunity lies against Congress. We may say that the two areas of civil and political liberty which the federal constitution grants to all citizens overlap in part only.

The fourteenth amendment raises a curious question. The first section contains the mandate that "No state shall make or enforce any law which shall abridge the privi- 
leges or immunities of citizens of the United States." What does this mean? What are the immunities in question? Does it mean that no state may abridge the immunities of a citizen from interference by the federal government, as, for example, the immunity which lies against trial in a federal court without a jury? How could a state do such a thing? Or does it mean that no state may abridge the immunities of a citizen which lie against the states, as, for example, the immunity against a law impairing the obligation of a contract? But no state can do this, even aside from the amendment. In fact, for a state to attempt by law the abridging of either class of "immunities of citizens of the United States" would be merely an unconstitutional act, which the federal courts would pronounce void at the first opportunity, even if the fourteenth amendment did not exist.

Does the amendment mean that all the immunities against federal action theretofore existing were taken over and made to lie also against the states? If this is the case, then the right of trial by jury in federal courts (Amendment VI) becomes by virtue of the fourteenth amendment also a right which applies to the state courts. But such a construction is certainly very farfetched. The amendment plainly forbids meddling with immunities already existing; it by no means creates any new immunities. This being the case, it can only be understood as converting a plainly implied prohibition on the states, forbidding them to interfere with the rights guaranteed to citizens of the United States by the federal constitution-"This constitution, and the laws of the United States which shall be made in pursuance thereof, and all treaties made, or which shall be made, under the authority of the United States, shall be the supreme law of the land; and the judges in every state shall be bound thereby, anything in the constitution or laws of any state to the contrary notwithstanding" (Art. VI, sec. 2) -into an express prohibition. It bestows no new immunity on the citizen and places no new prohibition on the states. It is redundant, so far as mere legal rights are concerned.

The citizen of the United States (Amendment XIV, sec. 1) is also a citizen of the state in which he resides, and the Supreme Court has held that these are two distinct citizenships, each having its own attributes, ${ }^{83}$ although both may inhere in the same person. The citizen of a state as such has immunities from the action of the state government - a sphere of liberty, in short, within which the state government is forbidden to intrude. These immunities are found first of all in the federal constitution, for whatever is therein forbidden to a state is of course forbidden also to the government, which is the outward embodiment and agent of the state. The people of the state might, if they so wished, be content with these restrictions, and might intrust to their government the whole plentitude of power left untouched by the limitations on state action found in the federal constitution. In fact, however, the states in their constitutions have placed further restrictions on their governments, thus, as has been seen, constituting a state bill of rights. Some of these restrictions are needless repetitions 
of prohibitions which the federal constitution places on the states; as, for instance, the Illinois constitution (Art. II, sec. 14) forbids legislation enacting an ex post facto law, or a law impairing the obligations of contracts, both being forms of legislation forbidden the states expressly by the federal constitution. ${ }^{84}$ Besides a few such repetitions, however, state bills of rights contain a list of immunities which their citizens would not enjoy but for the state inhibitions on their own government. The rights of free speech, freedom of religion, the writ of habeas corpus, trial by jury, and many other familiar immunities, belong to citizens of a state so far as courts and state laws are concerned, by virtue of the state constitution, and not at all by force of the corresponding provisions of the federal constitution, which, as has been pointed out, apply only to the federal government. There is nothing in the federal constitution which secures the citizen of a state against an established church set up by the state itself; indeed, Connecticut had virtually an established church until 1817. California has adopted an alternative for the grand jury, and any state may by amending its constitution do away with the petit jury altogether.

Immunities being defined in the organic law are of little avail to the citizen unless there is some way of securing them in fact. The barons of England who extorted Magna Carta from King John were well aware of this, and accordingly the sixty-first chapter of that venerable charter delegates to twenty-five barons the function of guarantors, giving them legal power to use force against the king or his agents in case of breach of the immunities. Modern law in the United States makes a more orderly and less rude provision to the same end by intrusting the guaranty of the immunities of the citizen to the courts. As guardians of civil liberty the courts have with us two functions.

The first of these is a phase of the judicial power which is peculiarly American that of interpreting the constitution and declaring void a statute discovered to be repugnant to any constitutional provision. ${ }^{85}$ This is a power given the courts for the protection of immunities which lie against a legislature, and is a very effective limit against legislative trespass on the restrictions of the organic law. While it is true that judicial interpretation holds a statute void only as applied to the case at bar, still the presumption always is that such a precedent will be followed in future cases, and the custom now is for such decision to be accepted quietly by all concerned as final. The power is not given to the courts in express terms, but is inferred from the supremacy of the constitution over any other legislation, ${ }^{86}$ and from the jurisdiction expressly given. ${ }^{87}$

Such a power of the courts is unknown to the law of Europe. In the jurisprudence of the German empire there are perhaps indications that the imperial court may in time interpret its powers in that direction, ${ }^{88}$ although by some German commentators this is strenuously denied, so far as related to imperial legislation. ${ }^{89}$ But some consti-

84 U. S. Constitution, Art. I, sec. 10, §1.

85 See especially the classic case of Marbury v8. Madison (1 Cranch, 137); also BRINTon Coxe, The Judicial Power and Unconstitutional Legislation, chap. 14.

${ }^{86}$ E. g., U. S. Constitution, Art. VI, sec. 2.
87 Ibid., Art. III, sec. 2.

88 Von Rönne, Staatsrecht der preussischen Monarchie, Vol. II, pp. 62,63 .

89 E. g., LABAND, Vol. I, pp. 551-8. 
tutions, like those of Prussia and Switzerland, expressly forbid the courts to question the validity of legislation. ${ }^{90}$

A second power of American courts for the protection of constitutional immunities lies in the various writs, most of them derived from English equity jurisprudence, whereby the executive branch may be restrained. The most important of these are the habeas corpus, by which the lawfulness of imprisonment may be judicially tested; the injunction, by which an officer may be forbidden to do an act which in the opinion of the courts violates fundamental rights; the mandamus, by which an officer is compelled to do an act by which individual rights may be attained. Of course, these powers of the courts may also have other ends, but they are discussed here solely in their relation to the question of securing immunities guaranteed by the organic law. These powers are unknown to courts on the continent of Europe.

Thus American courts, as guardians of the liberty of the citizen, are armed against unlawful acts of both the other great branches of government.

The Austrian constitution contains an elaborate bill of rights, which on paper would seem to make the Austrian state as free as the American. In fact, however, these rights are very imperfectly secured. The defect lies in the absence of such guarantees of freedom as are found in the United States. In the absence of judicial or other protection for immunities it is of little value to have them enumerated in swelling words in the organic statutes.

The immunities which cover the field of civil liberty - civil rights - belong to every citizen in the social states, but, as has been shown, lie against the government. In this these rights differ from those which inhere in members of the social state against one another. Such rights are also the creation of law-usually of statute or common law - and are protected by the executive and the courts. But they are entirely distinct from the immunities against the action of government which form a bill of rights. It was on that ground that the Supreme Court of the United States declared void an act of Congress designed to secure to all persons, without regard to race, equal privileges in hotels, theaters, railroad traims, and the like, purporting to guard the immunity of the fourteenth amendment: "No State shall make or enforce any law which shall abridge the privileges or immunities of citizens of the United States." The court held that this provision of the constitution merely forbade state laws of such nature, but had no reference to the action of private individuals, such as the owners of hotels and theaters. ${ }^{91}$

Some hold that the fundamental rights secured by a constitution exist by nature as inherent in man, prior to human law and independent of legal enactment -in short, that they are natural rights. The Declaration of Independence recites that "all men are created equal; that they are endowed by their creator with certain inalienable rights; that among these are life, liberty, and the pursuit of happiness." The consti-

90 Prussian Constitution, Art. 106, 8 1; Swiss Constitu91 Civil Rights Cases, 109 U. S. 3. tion, Art. 113. 
tution of Illinois repeats this formula of the declaration almost word for word as the first section of the state bill of rights (Art. II, sec. 1) - thus oddly embodying in a code of laws a declaration of a doctrine in political philosophy. The Declaration of Independence, one must remember, is not law. It is a political manifesto, with whose dogmas one may or may not agree, and which has no binding force on the courts. The immunities secured in a bill of rights have binding force on the judiciary; they are rights at all in the legal sense only because enacted into law as expressing the will of the political state. The question of natural rights belongs to the domain of philosophy, and no doubt leads to an interesting field of speculation. It has no place in the discussion of constitutional law, and has no relation to legal science in any form, excepting in so far as it may be one of the social forces which lead to the enactment of law. Constitutions are not concerned with natural rights, or with moral rights, but simply with legal rights.

Political rights, which cover the field of political liberty, as civil rights cover the field of civil liberty, as has been seen, include the right to hold office and the right to vote; in short, the right to share in government. The question whether either of these is a natural right is also a matter of political philosophy, not of law. Legally speaking, such rights exist merely because established by the will of the political state, whether in the constitution or in the statutes.

The guaranty of these rights lies partly in the courts, as in the case with civil rights, and partly in the other branches of government. For instance, each house of Congress is made the judge of the election, returns, and qualifications of its own members ${ }^{92}$ and this principle is very commonly followed in other constitutions. The origin of placing the guardianship of this political right in the houses of the legislature rather than in the courts lay in the peculiar circumstances of the development of the House of Commons in England. The predominance of the crown was so great that judges were merely tools of the king, and were used by him to secure pliant membership in the Commons. To remedy this evil the house insisted on reserving to itself the right to pass on contested elections - a right which was finally secured (1604). Since English courts have become independent, the reason for legislative power to judge such questions has disappeared, and accordingly since 1868 the courts once more are the guardians of this political right. It was found by experience that the house was likely to decide election cases on the ground of partisanship rather than of law or equity - a consideration not altogether without weight in the United States.

Our legislative bodies retain a peculiar judicial power, however, and a striking instance of its abuse occurred quite recently..$^{93}$ The political right of membership in the House of Representatives is determined by the constitution, and consists in age, citizenship, residence, and election-these and no more. ${ }^{94}$ Whoever has these four qualifications has a constitutional right to a seat in the House, and the House is constituted "judge of the election, returns, and qualifications" of its members in

92 U. S. Constitution, Art. I, sec. $5, \S 1$.

94 U. S. Constitution, Art. I, secs. 2 and 3.

931900 . 
order that no one who has the constitutional qualifications may be denied this right. It is to be noted that the power of the House as to the qualifications of its members is that of a judge; the power is judicial, not legislative, and can therefore extend no farther than to ascertain the fact whether a given individual has the qualifications laid down in the constitution. If the House goes farther than that, and prescribes other qualifications as conditions precedent, it is plain that such action is legislative, and is absolutely beyond the constitutional power of the House. From the state of Utah, in 1898 , a person was elected to the House who was charged with violation of the laws of that state against polygamy, and, believing him guilty, the House refused him admission.

There was no question that the person thus excluded possessed all the constitutional qualifications; he was duly elected, and his exclusion on the other ground was a gross violation of the constitution which constitutes a dangerous precedent. If the House is free to amend the constitution at will by adding further qualifications for membership, it may add any qualifications it pleases - a power which in times of great political stress may be used to secure a majority for a political party. The Utah member had a clear political right in the premises - his constitutional right to a seat - and his court, from which no appeal lay, wrought him a plain injustice. The Supreme Court would not have denied a right in response to popular clamor.

\section{CONSTITUTIONAL REVISION}

The last essential in a written constitution is a specific method of altering its provisions-the amending process. This has already been discussed in some detail under the head of "The Political State" (pp. 7-22).

It is an error to make this process so difficult that constitutional change is almost impossible; it is also an error for change to be so easy as to unsettle the relative permanence which should mark the organic law.

The Articles of Confederation, which formed the constitution of the United States from 1781 to 1789 , could be altered only by unanimous assent of the states. Unanimous assent could not be had, and when government under the Articles was a proved failure, a new constitution was adopted by a process which was illegal and revolutionary - quite as revolutionary as the declaration of 1776 , and quite as justifiable. Indeed, secession did not originate in 1860 with South Carolina. The thirteen colonies seceded from the British empire in 1775-76, and in 1787-88 eleven states seceded from the Union and formed a new one under the present constitution - the two states left outside coming in reluctantly at a later date. Taught by this experience, the amending process in the Philadelphia constitution was made dependent on the assent of three-fourths of the states.

Revision of the constitution may be total or partial - may result in a new organic law altogether, or in some amendment which does not alter the general character of the document. 
A distinction may also be made between drafting and proposing a scheme of revision, which we may call the initiative, and the enactment into law of amendment thus initiated.

It may be said in general that the American plan usually involves placing the power to initiate and the power to enact in different hands, and that as a rule in American constitutions the initiation of total revision is intrusted to a convention, while the initiation of partial revision is confided to the ordinary legislature. This is the case in the federal constitution of the United States. The Congress, by a twothirds vote in each house, may propose amendments, which then become law by enactment of the states, three-fourths being taken as expressing the will of the whole. In voting on a proposed amendment of the federal constitution the states are equal, each having one vote, as is the case in electing a president when there is no choice by the electors $;^{95}$ and the states vote indirectly, through their ordinary legislatures or through conventions called for the purpose. A federal convention for total revision has never yet been called under the present constitution.

In the states of the American Union partial revision is intrusted to the legislature, the amendment being submitted to a direct vote of the people for enactment. For total revision - which is not an uncommon thing, by the way - a convention elected for the purpose is the agent for initiation. As a rule, the plan of organic law drafted and recommended by a convention is also submitted for enactment to a direct vote of the people, although in not a few cases conventions have assumed to act with plenary power, and have therefore enacted into law without submission to the people the instrument drafted (as in case of the New York Convention of 1777, the Illinois Convention of 1818 , the Louisiana Convention of 1898 , and others, especially in southern states).

In European constitutions revision is usually left to the ordinary legislative agencies, with some restrictions as compared with ordinary legislation. ${ }^{96}$ The peculiar Swiss provisions for popular initiative in constitutional revision have already been noticed. ${ }^{97}$

The fundamental principle is that organic law should be as nearly as possible the directly expressed will of the sovereign $-i$. $e$, the political people. Switzerland and the states of the American Union reach this end by requiring a direct popular vote on the enactment of constitutions or of a constitutional amendment.

\section{THE SCHEDULE}

When a new constitution is formed it is necessary to provide for the transition from the existing system of government to that under the new plan. Provisions of this character are in states of the American Union usually grouped under the rather meaningless name of a "schedule." The schedule annexed to the Illinois constitution

95 U. S. Constitution, Art. V; ibid., Amendment XII.

97 Ante, pp. 14-17.

96 Ante, pp. 11-13; see also Borgeadd, Adoption and Amendment of Constitutions. 
of 1870 is a good illustration. Its preamble recites its purpose: "That no inconvenience may arise from the alterations and amendments made in the constitution of this state, and to carry the same into complete effect, it is hereby ordained and declared." Then follow twenty-six sections, providing elaborately for a popular vote on the question of accepting or rejecting the proposed constitution, for the continuance in office of existing officials until new ones should take their places, for a legislative apportionment, and for the election of a new legislature. Other sections continue existing laws and existing public liabilities, and make a variety of other stipulations, the most of them essential to avoid confusion in passing from government under the old constitution to government under the new.

The schedule of the Illinois constitution of 1818 was curious in that it contained certain sections which in reality were additional parts of the constitution. Thus, sec. 11 runs as follows: "It shall be the duty of the general assembly to enact such laws as may be necessary and proper to prevent the practice of duelling." Sec. 10 vested in the general assembly a vast appointing power: "An auditor of public accounts, an attorney-general, and such other officers of the state as may be necessary, may be appointed by the general assembly, whose duties may be regulated by law." Sec. 14 was odd: "Any person of thirty years of age who is a citizen of the United States and has resided within the limits of this State ten years next preceding his election, shall be eligible to the office of lieutenant governor; anything in the thirteenth section of the third article of this constitution contained to the contrary notwithstanding." Art. III, sec. 13, required one to have been for thirty years a citizen of the United States in order to be eligible to election as lieutenant governor. The president of the convention was Pierre Menard, a native of Quebec, who, although long a resident of the territory, was not naturalized until 1816. It had been arranged by the politicians that Menard should be elected lieutenant governor, and hence sec. 14 of the schedule was added in order that he should be qualified.

In the federal constitution of the United States the only provision looking to the transition from government under the Articles of Confederation to government under the constitution was Art. VII: "The ratification of the conventions of nine states shall be sufficient for the establishment of this constitution between the states so ratifying the same." All details were by implication left to the existing Congress of the Confederation, which body in fact adopted all the measures necessary to put the new government in motion.

\section{SUBJECT-MATTER GERMANE TÓ A CONSTITUTION}

The present constitutions of many of the states in the American Union have been criticised as containing much matter which should rather be statutory. There is no doubt that the tendency of state constitutions has been to increase greatly in bulk, as has already been pointed out (p. 29), and it is equally clear that on the whole the increase is caused by progressively closer restrictions on the powers of the legislature. 
That such restrictions are improper in the organic law, however, is not so evident. The extent to which the people prefer to limit the powers of their agents, the government, is wholly a matter of judgment. Any restriction whatever which the sovereign people choose to embody in the constitution - in other words, any provision of law which it is the will of the people to put beyond the power of the legislature to alteris germane to the restrictions normally found in a constitution, and it is a shallow criticism which would condemn them on such grounds.

Whether any given provision of this character is in itself wise is quite another question. Its wisdom or lack of wisdom as legislation, however, has nothing whatever to do with the propriety of embodying it in the constitution. There can be no doubt that there are constitutional provisions, as to a still greater extent there are statutory provisions, which are inexpedient and improper because they do not in fact represent the will of the people. The persistent clamor of an active group not infrequently induces a legislature to enact a measure which it does not itself approve and which a majority of the people do not want. If the irritation is sufficiently great it is likely that a subsequent legislature will repeal the act. But quite often the people leave the measure on the statute books and quietly disregard it. Much temperance legislation and legislation for Sunday observance are of this character. Many good people have their ardor for reform satisfied by the mere enactment of a law, apparently not realizing that a law is merely a means to an end, and that laws are by no means always self-executing.

Indeed, unless law is in fact what it is in form, the will of the people, it cannot easily be enforced. In other words, there should be a correspondence between legislation and social opinion such as to put behind the government a social force which will imperatively constrain obedience to the mandate of law. This is not the case with much legislation which seeks to regulate conduct only remotely affecting the interests of others than persons whose acts it is sought to restrain. Certain forms of gambling, certain amusements, or certain kinds of business on Sunday are forbidden by laws which illustrate this principle. Law should be the crystallization of general public opinion, not the merely hortatory expression of the views of a small portion of the community. The embodiment in the organic law of this last character of legislation is especially unfortunate. Its impropriety, however, does not come from the nature of the acts which it forbids, but from the fact that it is not the true will of the constituent people.

It is plain enough that the enforcibility of law, whether constitutional or statutory, may depend also on the nature of the rights or duties which it establishes. A law specifying conditions of title to real property is easily enforcible, because failure to conform to its provisions at once vitiates such title and canses immediate inconvenience. A law requiring a limit of age for the employment of children in factories is not so easily enforcible, because there is often a strong motive for its evasion, and because it is not always easy to determine the age of a child who may be somewhat under the legal 
limit. In other words, some provisions of law, including the organic law, may be called self-executing, while others are not.

In applying these principles to the organic law it should be observed that constitutional provisions which are not self-executing necessitate legislation to carry them into effect. In the absence of such legislation the provisions in question become dormant and, for the time being, of no effect. Such a provision is, as has already been pointed out (p. 34), the power of Congress to make uniform laws on the subject of bankruptcies. Legislation of this kind may then itself also be enforcible easily or with difficulty, according to its nature.

\section{OBEDIENCE TO LAW THE ESSENCE OF AN ORDERLY STATE}

Legislation of any kind, and especially that of the constitution, which is of such nature as easily to fall into desuetude, is a serious misfortune. It tends to weaken respect for law-and respect for law and willing obedience to its mandates are the essence of an enlightened modern community. Especially is this true of the organic law. Reverence for the constitution is the choicest political virtue of a free people. Disregard of constitutional rights and duties is the fruitful seed of anarchy-a form of anarchy with which some American republics have been cursed for generations. A nation which has not learned to hold its constitution sacred and to obey readily even a law which is irksome, is not yet fit for self-government. A free people must be preeminently a law-abiding people - and the supreme law is the constitution.

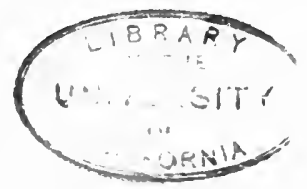


RETURN TO the circulation desk of any

University of California Library

or to the

NORTHERN REGIONAL LIBRARY FACILITY

Bldg. 400, Richmond Field Station

University of California

Richmond, CA 94804-4698

ALL BOOKS MAY BE RECALLED AFTER 7 DAYS

- 2-month loans may be renewed by calling (510) 642-6753

- 1-year loans may be recharged by bringing books to NRLF

- Renewals and recharges may be made 4 days prior to due date

DUE AS STAMPED BELOW

MAR 022007 









$$
\begin{aligned}
& \therefore+\cdots 2
\end{aligned}
$$

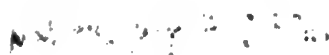

$$
\begin{aligned}
& \therefore: \because .
\end{aligned}
$$


